2015-08-18

\title{
Miniaturisation and the representation of military geographies in recreational wargaming
}

\section{Yarwood, Richard}

http://hdl.handle.net/10026.1/3968

\subsection{0/14649365.2014.1001430}

Social \&amp; Cultural Geography

Informa UK Limited

All content in PEARL is protected by copyright law. Author manuscripts are made available in accordance with publisher policies. Please cite only the published version using the details provided on the item record or document. In the absence of an open licence (e.g. Creative Commons), permissions for further reuse of content should be sought from the publisher or author. 


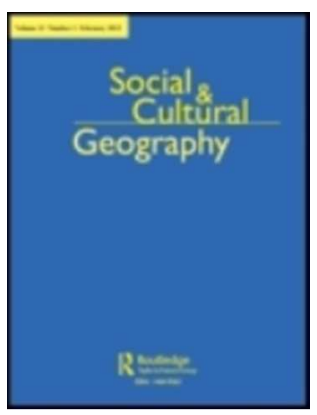

\section{Dicing with Death? Miniaturisation and the Representation of Military Geographies in Recreational Wargaming}

\begin{tabular}{|r|l|}
\hline Journal: & Social and Cultural Geography \\
\hline Manuscript ID: & RSCG-2014-0123.R1 \\
\hline Manuscript Type: & Original Paper \\
\hline Keywords: & $\begin{array}{l}\text { military geographies, banal geopolitics, wargaming, miniaturisation, } \\
\text { leisure, play }\end{array}$ \\
& $\begin{array}{l}\text { Miniaturisation affects space in many ways: projecting it, transforming it } \\
\text { and co-producing it with those who make and gaze upon models. This } \\
\text { paper draws on Susan Stewart's (1993) work 'On Longing' to demonstrate } \\
\text { how concepts of miniaturisation have the ability to contribute to } \\
\text { geographical study. The empirical focus for the paper is a study of scale } \\
\text { models deployed in the hobby of miniature or figure wargames in which } \\
\text { players fight battles on the table top using model terrain and miniature } \\
\text { figures. In this paper I use examples of scaled terrain and figures to } \\
\text { explore the process of miniaturisation and how this represents and } \\
\text { transforms space. In doing so, the paper contributes to understanding the } \\
\text { ways in which military geographies are represented through the media of } \\
\text { models and performances of playing with them. }\end{array}$ \\
\hline
\end{tabular}




\section{Introduction}

In a community hall in the suburbs of an Australian city, two model armies are arrayed against each other on a table-top swathed with model scenery depicting a desert plane. Each army comprises of $15 \mathrm{~mm}$ high figures that have been exquisitely painted by their owners who sit on opposite sides of the table. One army represents that of Alexander the Great, the other his Persian enemy. The models are grouped into units that represent different troop types: archers, pikemen, light cavalry, chariots, heavy cavalry, elephants ... Battle commences: each player moves his (both are men) models over model terrain according to a set of rules that determines how far and fast they can move in a 'turn' of play. The lines of troops meet and a series of battles ensue ... on the flanks cavalry vie for position; in the centre phalanxes are advanced in an effort to gain a decisive victory; skirmishers harass each other; catapults fly and always there is the menace of elephants poised to crash through opposition lines. Dice are thrown ... figures are removed, other fall back in retreat. Rules are consulted, sometimes argued over, and the game moves on. Gradually, over a series of turns, one army starts to crumble as its troops are destroyed or flee. In desperation the general throws reserves into his line but these too are swept away by the victorious army. As the game ends, players shake hands and carefully pack away their troops and terrain to be deployed another time. An evening has passed and, outside the hall, the suburb is now in darkness (Observation at an Australian wargaming club)

The miniature world is a world of arrested time; its stillness emphasizes the activity that is outside its borders. And this effect is reciprocal; for once we attend to the miniature world, the world outside stops and is lost to us (Stewart, 1993: 76)

In her book 'On Longing', Susan Stewart (1993) describes how three-dimensional models or toys have an ability to draw the viewer into scaled-down worlds that seem to exist independently from reality. Observers of models are, as these opening quotations suggest, drawn into the space of the model yet, at the same time, exist 'outside the possibility of a 
lived reality of the miniature' (Stewart 1993: 76). This dilemma is only resolved through the imaginative and performative use of miniatures. The collection, display and use of miniature objects mediate the experience of time and space to create 'an "other" time, a type of transcendent time which negates change and the flux of lived reality' (Stewart, 1993: 65). Miniatures affect space in multiple ways: projecting it, transforming it and co-producing it with those who make and gaze upon models. Scale, place, representation and performance are also central to the process of miniaturisation, suggesting it should be of greater interest to geographers.

Contributing to emerging work in this area (Koch 2010; Yarwood and Shaw 2010; Woodyer 2012), this paper draws upon Stewart's work to argue that the concept miniaturisation warrants greater attention in geographical study. The empirical focus is a study of scale models deployed in the hobby of miniature or figure wargaming in which players 'fight various tactical battles on the table top using model terrain and miniature figures' (Sabin 2012: xviii). The activity is carried out largely for recreation and is played, usually by adults, as a game in which rules, tape measures and dice are used to determine how model armies manoeuvre, fight and react to orders in battle (Figure 1). I draw upon interviews with wargamers, observations of their games and readings of hobby literature in an effort to understand its 'inwardly orientated politics' (Woodyer 2012: 322) and the ways in which miniaturisation contributes to the representation of military geographies.

The paper has three main aims. First, I introduce Stewart's ideas on miniaturisation and demonstrate their potential to inform geographical study. Second, I use the hobby of recreational wargaming to explore the relationship between miniaturisation and space. This example is pertinent because wargaming is an inherently geographical practice that is based on representations of geo-politics, the control of territory and scaled representations of people and places. Following an introduction to wargaming, attention is given to the way that games 
are re-produced through hobby networks and the interiority of those that play them. In doing so, I support developing work in ludic geographies (Woodyer 2012) by emphasising the importance of play to the process of miniaturisation. Thirdly, I reflect on the ways that war is represented through hobby and lay networks. This contributes to knowledge in the growing field of military geographies and the ways that the military is imagined in different spaces (Woodward 2013). I question whether these representations vary significantly from other media representations, especially those produced by military-entertainment networks, and in doing so demonstrate the value of miniaturisation to critical social and cultural geography.

\section{Miniaturisation}

Miniaturisation is powerful because it can be used to coerce or manipulate the observer into seeing the world in a particular way. The viewer is placed in a position of power, with a panoptic ability to look down on a scene and, perhaps, share a view and vision that are usually the privilege of the powerful (Stewart 1993). This is encapsulated by de Certeau's (1984: 92) image of the viewer gazing down from a skyscraper from a height that offers a totalizing perspective that offers the "pleasure of "seeing the whole".

Natalie Koch (2010) demonstrates this in a study of architectural models, noting how they can transform places from sites of contest to 'sites of elite-defined modernity' (779). Their power comes from a miniature's ability to provide 'absolute closure' on a discourse. Stewart (1993: 66) argues: 'whereas speech unfolds in time, the miniature unfolds in space ... the miniature is against speech'. In part, as Koch (2010) demonstrates, miniaturisation invites the viewer to see the world in a gargantuan, panoptic way, sharing and perhaps enrolling themselves into the state's vision of a place with little awareness of alternative possibilities. Models in museums can present particular forms of history, frozen into a particular vignette that appear to define and authenticate a vision of history (Chivallon 2001; Insley 2008). 
Varutti (2011) notes how that miniatures in Chinese museums oversimplify inter-ethnic relations but appear 'real' by virtue of their detail and animation. In Indonesia, a public model portraying 'Beautiful Indonesia in Miniature' is an effort authentic the cultural and political letigimacy of the New Order government (Pemberton 1994). A further example is provided by Captain William Siborne's model of the Battle of Waterloo, which was commissioned by Britain's commander-in-chief and completed in 1838 (Hofschroer 2004). It is a remarkable panorama of the battlefield, comprising 75,000 model soldiers painstakingly arrayed on modelled terrain that stretches over four hundred square feet. As the viewer is drawn in by the model's realism, he or she assumes that it is an accurate representation of the 'real thing'. However, the model-maker was obliged to omit the Prussians from his model by Wellington as part of a wider discourse that sought to present Waterloo as solely a British victory (Hofschroer 2004).

Equally, models of ships, planes and vehicles celebrate triumphs of technology and industrialisation. A model is a fetishism of commodity that hides the political-economic factors that shaped it and its real-life counterparts. Many models, such as Airfix kits, are themselves mass-produced as part of enterprises that seek to market particular projections of authenticity for commercial gain. In this way miniatures recognise and absorb 'false realities', acting as a simulacrum that is detached from the reality it seeks to project (Baudrillard 1994).

Although scale miniatures reflect and celebrate power relations they also rely on personal, performative and imaginative actions to mobilise their power. Stewart demonstrates that a miniature can be seen to reflect its processor's interiority (personal experience, beliefs and memories) as much as externally driven discourses of history or authenticity. A mass produced model can be transformed as the modeller becomes an artisan, able to imbue his or her characteristics on a model (Campbell 2005) through the 'serious pursuit' of assembling, painting, using and displaying scale models (Heley and Jones 2013; Stebbins 2001; 
Yarwood and Shaw 2010). Perhaps most significantly, playing with a model offers one way of negotiating the internal and external narratives that surround a miniature. It is the everyday practices of playing that exceed representation and offer the momentary 'possibility of configuring alternative ways of being-in-the-world' (Woodyer 2012: 320). Play animates a miniature and helps to produce new, imagined worlds. As Shaw (2010: 793) reminds us 'much of the fun found in play is the blurring of these lines into a mixture of objects and sensations that are not quite 'self' or 'world', Put more simply:

\footnotetext{
a game is an activity characterised above all by the fact that it creates its own little world ... with the space where the game is held, and for as long as it lasts, cause and effect are abolished. The nature of the activity does not matter much. As long as it is done for "fun", as people say, almost anything may be turned into a game (van Creveld 2013: 1-2)
}

Play is not just a way of representing the world but is its participants' world. Shaw (2010: 793) describes play as "neither a psychic invention nor a matter of external reality; it is instead a transitional space where both forces co-mingle and produce an emergent, immanent and affective experience'. Play, then, is an important part of the way in which miniatures transform space. Significantly, play opens up the possibility of different ways of seeing, imagining and performing 'real' space. Saville (2008: 910) argues that 'it may be that in play, and not just amongst young children, that we can find ways to break out of iterative performances, not only of mobility, but of emotionality as well.' Play has the potential to be a liberating experience for the individual and to bring different voices and experiences to miniature spaces (Griggs 2009; Heley and Jones 2013; Moser 2010; Shaw and Sharp 2013; Stebbins 2001; Woodyer 2012). It is the movement of miniatures through play (for example, running a model railway (Yarwood and Shaw 2010)) that transforms the space of the model from a static to an active one that opens up different imaginative possibilities. 
Stewart's ideas on miniaturisation chime with current debates about the use of scale in geography (MacKinnon 2010; Herod 2011). These centre around political economy perspectives that view scale as a product of wider political-economic processes concerned with the reproduction of capital (Swyngedouw 2000); and post-structural critiques of this notion that view scale as something that is performed discursively through social practices, rather than something that ontologically pre-exists social activity (Moore 2008). MacKinnon (2010: 28) argues that both approaches have value and draws upon critical realism to view 'scales as 'real' material entities, which are known and understood through particular social representations and discourses'. While MacKinnon's work draws attention to the way in which scale is used by different political actors, Stewart adds social and cultural dimensions to this: miniatures can serve political purposes but, at the same time, reproduce personal, somewhat apolitical visions of space.

To examine these themes further, the paper explores miniaturisation through the hobby and practises of wargaming. Although there is a wide academic literature on wargaming (see books by Allen, 2002; Cornell et al., 2002; Dunnigan, 2005; Lewin, 2012; Sabin, 2007; Sabin, 2012; van Creveld, 2013 and the academic journal 'Simulation and Gaming'), geographers have paid scant attention to it. This perhaps reflects that wargaming has been stigmatised 'to the point where most people either are not aware it exists or see it as a faintly disreputable and juvenile activity, unworthy of further investigation' (Sabin 2002: 193). Nevertheless, the following section argues for its inclusion within the remit of social and cultural geography.

\section{Little Wars}


There is a long history of games based on warfare (Cornell and Allen 2002; Peterson 2012; Lewin 2012; Smith 2010). They include Wei-Hai that originated in China in 3000BC and became 'Go'; the Indian board game Chaturanga that evolved into Chess; 'Kreigspiel', a game devised by the Prussian military in the 19th Century to train officers and, more recently, computer games used by both civilians and armed forces personnel (Huntemann and Payne 2010; Shaw 2010). 'Wargaming' embraces many undertakings that range from training exercises carried out by actual troops to more playful activities such as paintballing or board games based on fantasy or science-fictional worlds (Der Derian 2009; Graham 2010; Hyde 2013; Macedonia 2002; Sabin 2002, 2012; Smith 2010; van Creveld 2013). All forms of contemporary wargames ostensibly draw on two inter-related traditions: one driven by the military and another by hobby networks.

\section{Wargaming and the Military}

In terms of the military, one of the most influential simulation games was 'Kriegspeil', an exercise devised by the Prussian military in the nineteenth century (Hyde 2013). It used wooden blocks to represent military units that moved and fought across tables with various forms of terrain placed on them. An umpire determined the results of movement and fighting using a set of rules. The aim was to provide a realistic simulation of war in order to train officers; a tradition that has been continued in the development of simulation games for educational and training purposes (Sabbin 2012).

The principle of using games to simulate warfare has been developed with increasing sophistication since the inception of Kriegspeil. In some cases they have been scaled up and used in training exercises for real troops. Graham (2010) details how specially designed settlements have been developed by the military to providing authentic training venues to simulate combat and security situations in 'other' places. Great attention is paid to making 
these experiences as realistic as possible through the employment of actors drawn from particular ethnic groups and the use of Hollywood style effects. Principles derived from gaming, including rules, scenarios and the use of umpires, are used to determine how these exercises are 'played out' (see also Anderson and Adey 2011).

Indeed, many commentators have suggested that there is a blurring between simulations used by the military for training and games played for recreation. Der Derian (2009 xxvii) has referred to a growth in the 'military-industrial-media-entertainment' network (MIME-NET) that has merged the distinction between real and imagined combat: 'made for TV war and Hollywood war movie blur, military wargames and computer video games blend, mock disasters and real accidents collide'. Video games bring war into living rooms (Deterding 2010), creating what Graham and Shaw (2010) have termed a transitional third space between military and civilian lives that, in turn, has helped to enrol the public literally (through recruitment of gamers) and imaginatively to the military's task (Allen 2002; Gregory 2010, 2011).

These developments may contribute to a form of banal geopolitics, in which war is viewed as the norm and conflict an expected occurrence (Sidaway, 2001). Sidaway (2008) argues that complex political issues are simplified to rationalize military actions to the extent that they become driven by cultural associations rather than political justification. As the study of banal geopolitics encourages us to consider the everyday spaces that reproduce geopolitical relations, there is scope to consider the place of wargames in this process. Although attention has been given to the use of video games such as 'Marine Doom' and 'America's Army' to train troops and/or transform civilians into 'virtual troops' more likely to sympathise or even empathise with the military's role (Allen 2002; Shaw 2010; Stahl 2006), miniature wargaming have received less consideration. This is because they have had 
less direct intervention from the military and, instead, have developed from games with toy soldiers.

\section{Miniature Wargaming for Recreation}

The recreational tradition of wargaming places more emphasis on play than simulation. In 1913 H G Wells published 'Little Wars' (Wells 1913) that described a set of rules for recreating battles with toy soldiers using a formal sequence of 'turns'. It detailed how different troop types could move, use cover, cross different types of terrain (represented by toy bricks), engage in hand-to-hand combat, shoot and take prisoners. Gunfire was simulated by physically shooting at model troops with breach-loading toy guns that fired wooden shots. This element of physical skill distinguished it from Kreigspiel and, indeed, later sets of wargames rules that used calculations, rather than physical skills, to determine casualties.

The modern hobby of miniature wargaming was developed by lay, amateur writers and emerged in the latter half of the twentieth century, mainly in the UK and USA (Hyde 2013; Sabin 2002). Donald Featherstone published one of the first books on the topic, 'Wargames' (Featherstone 1962), which established many of the principles of the modern game including rules to determine movement, firing, meleeing and morale. Featherstone and other authors published further books that contributed modified sets of rules, scenarios and historical essays to aid the playing of wargames. These publications established wargaming as a 'serious' leisure pursuit (Stebbins 2001; Sabin 2002; Hyde 2013) by encouraging readers to research the history of the warfare, collect and paint authentic model armies, produce their own terrain and even manufacture figures. As the hobby grew in popularity, numbers of commercially available rules, figures and models increased.

\section{Research Focus}


For the remainder of this paper, I turn my attention to these historical miniature wargames played with figures. This is for three main reasons. First, although models may seem in some ways old-fashioned compared to computer-generated images, they remain a lively strand of simulating military actions that allow us to explore Stewart's conceptualisation of miniaturisation. She argues that the three-dimensional, scaled nature of miniatures draws in the viewer, leading to what she describes as an 'infinite time of reverie' (Stewart 1993: 65) that blocks out reality and immerses the viewer in the model world. While video games are doubtless played enthusiastically and immersively by networks of players, the imaginative boundaries and features of games are determined by software companies and games consoles. Miniature wargames, by contrast, allow greater opportunities for more creative acts of self-expression through collection, painting and organisation of model armies and the writing of rules to control them. Scale models are, I contend, a unique media that have ability to capture and represent imaginative performances in ways that are perhaps absent from two-dimensional or virtual media.

Second, unlike computer games, the hobbies of miniature wargaming and scale modelling have had little direct intervention from the military itself. Sabin (2002: 195) notes that an interest in 'military affairs', characterised by 'militaria, reading and battlefield tours', have made a greater contribution to wargaming than interventions by the military themselves. Wargames are co-produced by commercial manufacturers, amateur historians, clubs, specialist media and key figures in networks of 'craft consumption' (Campbell 2005; Yarwood and Shaw 2010). It is these networks that determine the authenticity of a model. Crang (1996: 428) notes in the case of English Civil War re-enactment societies: 'authenticity was not so much found in the past as in the communitas felt with others equally both trying and admitting the impossibility of ever achieving it.' It is valuable to consider how the representation of war by hobby networks differs from that of MIME-NET. 
A third reason for focusing on minitaures is that, beyond criticisms of the ways 'war toys' glorify killing (Beresin, 1989; Varney, 2000), there has been curiously little attention to the ways that the military has been portrayed through scale-models. This is despite growing interest in the ways that video games (Der Derian 2009; Huntemann and Payne 2010; Shaw 2010; Shaw and Sharp 2013; Stahl 2006), films (Carter and McCormack 2006); landscapes (Muzaini 2013; Woodward 2013), memorials (Marshall 2004; Purvis and Atkinson 2009) and various other media (Dodds 1996; Woodward and Jenkings 2012; Woodward and Jenkings 2011) have portrayed military and geopolitical events (Woodward 2005). Yet scale models are some of the most long-standing and widely encountered representations of the military, continuing to be widely found in high street shops, children's rooms and various places of indoor leisure (Peterson 2012; Sabin 2012; van Creveld 2013). There is scope for more a more nuanced engagement with models and those who use them. Their study moves analysis beyond how the military is represented towards understanding how military spaces are produced through the imaginative performance of play.

The work presented in this paper draws upon visits to nine wargaming conventions and clubs in the UK and Australia where gamers were interviewed while playing historical wargames with miniature figures on three dimensional, modelled terrains. It builds upon Sabin's (2002) study of recreational wargamers that suggested that the hobby was practised by socially elite groups of people who were almost exclusively male, well-educated, from professional occupations and middle aged (having been introduced to the hobby in their teens). The aim was not to repeat this analysis but, rather, to focus on the imaginative and performative use of miniatures in wargames. Thus, games served as a prompt for respondents and allowed them to talk enthusiastically about the specific game being played, for example pointing out intricacies of the rules or details on their models, as well as more general aspects of the hobby. The games covered a wide range of historical periods and scales. These 
differences are significant to those in the hobby and allowed different forms of enthusiasm (Geoghegan 2013) to manifest themselves in the interviews. Non-participant observation also allowed games to be watched in their entirety and acted as a prompt for respondents to talk about their hobby and collections. The interviews were semi-structured, inductive discussions that were taped with the permission of the respondents. With the exception of one woman, all respondents were white, middle-aged men.

Hobby conventions were chosen as the primary focus of research because, as Yarwood and Shaw (2010) point out, they are sites that are co-created by the networks of production, consumption and performance that circulate between the spaces and actors of a hobby. They host trade stands where models are brought, examined and sold as well as various forms of games. These include 'exhibition games', which are staged to showcase the hobby and have very high standards of modelling; tournament games that are played competitively for prizes; and participation games, which encourage members of the public to join in and try out wargaming for themselves. Conventions therefore provide an opportunity to examine how wargaming is co-produced by different practices and discourses that, together, constitute the hobby. The fieldwork is supported reference to the considerable grey literature that surrounds the hobby, including rule books and their supplements, magazines, books, trade catalogues, reference works and websites that contribute to the way that wargames are played.

\section{Miniature Worlds at War}

Miniature wargames use three-dimensional terrain and figures at scales that vary depending on the type of game, period, the commercially availability of figures and what is deemed fashionable in the hobby. Smaller scales $(1: 1250,1: 300)$ are favoured for large, naval or modern battles fought over large distances; larger scales (1:54) for skirmish games with a few 
figures. The majority of games use $15 \mathrm{~mm}, 20 \mathrm{~mm}, 25 \mathrm{~mm}$ or $30 \mathrm{~mm}$ figures that are small enough to allow battles to be scaled down on a table top but are also large enough to be painted in detail. As Figure 2 demonstrates, the results can be visually stunning, capable of provoking what Woodyer and Geoghegan call 'enchantment' (2013: 196) or 'delight, wonder or that which cannot be simply explained'. This not only stems from the look of the game but a respect for the skill and effort put into creating it. Peterson (2012: 14) notes:

Weeks might be spent constructing the battle ground alone in which trees man-made [sic] structures, gravel roads and so on are selected for maximum verisimilitude. Researching a historical battle or period to the lay of the land as well as the positions and equipment of the combatants is a task which can exhaust any investment of time and energy.

The finished products are an assemblage not only of materials but skills, time, technology and knowledge. One modeller said:

I like doing scenery, again recreating ...you find that you learn so much, it's not just the troops and what they are wearing because you can find out what colours they would be wearing. Well you end up learning about dyeing in the Middle Ages, dyeing cloth that is.

This hints at the level of immersion that can go into producing the miniature world of the wargame. The emphasis on authenticity means that the table-top is not only an image of the world but reflects its maker's personality or interiority (Stewart 1993), in these cases the endeavour and skill put into creating it.

As games are played, the imaginative possibilities of miniature terrain unfold: hills are objectives to be fought over, a river crossing has tactical significance and a marsh prevents an orderly retreat. Something of this is captured in the following extract from an interview in which the respondent described his re-production of the battle of Cambrai in 
1917 (the first time massed tanks were used in battle). As the speaker talks he points out features on his model terrain, animating a historical battle with his models:

The infantry were moved up during the night to within two hundred yards of the trenches without the German's knowing. And the tanks then in the morning rolled up [points to model tanks]. The Germans were having a look and wondering what the hell this was because they had never seen them. It was totally new to them [gesticulates to the model trenches and figures inside them] Then an artillery barrage just hit them and so they went into their trenches and normally it would take them probably half an hour to come back out and set up position. Well the British infantry were already within 200 hundred yards so as soon as the tanks had actually punched through the wire the British were in and on the German's before they had even got into their proper positions and caught them by surprise [demonstrates with a piece of gamed action that sees a tank advance successfully].

The extract reveals a 'desire to re-invent a world, a world which 'works"' (Stewart 1993: xii). The player is able to reproduce the battle as it 'should have gone', rather than experience any of the mistakes that occurred historically to the cost of people's lives. Thus, one gamer commented that he was recreating a specific medieval battle as it allowed him to evaluate different tactics:

This is based on an actual battle; I say a battle, it was a rout more like than anything else. I think my tactics aren't actually right. Tomorrow we are going to do it differently where we just advance straight into them.

Here play gives gamers the opportunity to recreate different versions of what might have been. Van Creveld (2013: 8) goes so far as to say that wargaming provides better representation than historical events:

Reality after all is an ever-shifting, elusive thing. It exists, if at all, for only a moment and that moment very may well be untypical. That is why some representations of it capture its 
essence better than reality itself ... wargames provide a singularly useful tool to understanding the nature of war and the way various societies related to it.

Whereas the creativity of video games offers the opportunity to 'reflect upon futures that may come to pass' (Shaw and Sharp 2013: 345), miniature wargames question what might have been. Koch (2010: 779-780) argues: 'it is precisely this infinite time of reverie that makes the model miniatures so powerful - they create an alternative, utopian temporarility'. Deleuze (1989) argues that to consider battle as one 'true' event is misleading and, instead, it should be considered as something virtual that is imagined through different standpoints and perspectives. The reality of actual, seen battle is false. Generals can never achieve the panoptic view of their troops afforded to wargamers. Yet, wargames create this illusion and, while it last, plays see the world through as if they were a general, imbued with the power and vision to control the troops in an imagined world. As Koch (2010) argues, this momentary vision enrols the gamer into the gaze of the powerful, creating, in this case an empathy with the military gaze.

This is not only driven from external discourses but internal ones as well. Stewart's (1993) work emphasises the importance of a collector's beliefs, ideas, use and personal interpretation of miniatures. Amateur wargaming provides a perfect illustration of this as the power to order and control space and time can be seen in the collection, painting and organisation of model figures into scale armies. As the following section discusses, these activities are just as important, if not more so, as playing the games themselves.

\section{Collecting and Painting}

Unpainted plastic or metal figures are bought from commercial manufacturers and much time and skill is invested in painting them and organising them into armies. Decisions about what 
to collect and how to paint figures, allows a gamer to 'invest his or her personality or self into the object produced' (Campbell 2005: 27). One respondent listed his current work:

\begin{abstract}
I'm actually just finishing off all the World War Two I've collected over the years and not painted or based. Boxes and boxes of soldiers! And some of that stuff I'm never going to use. I've just got rid of a Franco-Prussian [1870] French army. I'm not going to use it, I don't want it. It was a good idea when I started it but I'm not going to use it so I got rid of a load of kits as well as I thought I'm never going to make them and I've got a million German soldiers.
\end{abstract}

Collecting is an on-going process: an army is rarely completed and, even then, new armies and figures are collected or discarded (Crewe and Gregson 2003). The collection of figures is imaginative as well as performed, with plans for future forces foremost in the mind of collectors.

Collecting creates its own temporality by replacing 'history with classification, with order beyond the realm of temporality' (Stewart 1993: 151). Collections take events from the past, reimagine them and converted into property that can be displayed in contemporary spaces. Indeed, classification is particularly important to wargamers who organise their armies in accordance with 'Army Lists' that are published by rule-writers to determine number and balance of units in a scale army. Organisation develops its own temporarility and spatiality, rather than reflecting or reproducing the past: 'to arrange the objects according to time is to juxtapose personal time with social time, autobiography with history, and thus to create a fiction of the individual life, a time of the individual subject both transcended to and parallel to historical time' (Stewart 1993: 154). In other words, collection asserts a degree of control over time and space that is realised in the world of the miniature. 
These spaces offer an opportunity for gamers to engage in what Campbell (2005: 24) has termed 'craft consumption' or the ability to buy and use products to 'engage in creative acts of self-expression'. One gamer said:

I like the weak armies, the underdog. I've some World War One figures and I've chosen the Serbian Reserve army and I've got an early British World War Two army with Mark One Matildas and Vickers light tanks [which were outmatched in battle by their German counterparts]

The respondent went on to say that 'underdog' armies offer a chance to explore little known aspects of military history to re-assess the performance of these armies. These armies are not widely available commercially and so offer a greater possibility for the craft consumer to invest more of themselves into it, perhaps by converting figures. An unusual army makes a greater statement about the individuality of the gamer (Campbell 2005). It is important, though, to note that these collections are co-produced in relation to wider hobby networks. One interviewee stated:

A common thing to happen is that people see new figures in a new scale that really appeals to them and they really want to buy and very often they persuade a mate to buy the opposing army so you get a little group or new campaign with nice figures.

This was confirmed by another gamer who recounted how this had led him to devise a game based in late nineteenth century Africa:

A series of figures had just been released and we really liked the figures ... 6 mil is good for a mass effect.

Here the decision to game the period was driven by a commercial release, rather than a specific interest in that period. The small scale (6 millimetre high figures) allows many figures to be represented at a 1:1 scale, allowing the spectacle of a mass battle to be 
communicated. These choices are shaped by sets of rules that are commercially produced and, increasingly, are increasingly tied into specific sets of commercially available figures (Hyde 2013). Yet, although wargaming reflects mass production and indeed the mass production of total war, miniatures can still display the interiority of their owners. Painting offers this opportunity.

Figures are supplied unpainted and so their embellishment demonstrates skills as a modeller including the use of shading and highlighting techniques to bring out the best in a figure. Indeed, some armies are collected because they offer opportunities for painting:

There's a romance around them. Napoleonics, it's just those bright uniforms. You've got Napoleon there with that aura ... it's colourful and it's got all the painting you want to do.

The attention paid to painting of buttons, sashes, epaulettes, facings and other points of detail marks a transformative process that distinguishes model from toy soldiers through its attention to scaled accuracy. The way and extent to which figures are painted is a personal choice, so that the finished figure reflects its painter's tastes personality, as well as skill:

I mean I can never be bothered with the sort of people who paint in so much detail... the amount of time it must take to paint. I said to someone earlier people paint their knuckles. Why? What for? It looks bloody stupid anyway. Accuracy's important but I mean I always take the view of [name of wargamer] you paint accurately but you're still simulating a figure seen at a distance so you are selective with the details. I mean if you pick [one of my] figures up ... close up I still think they are still reasonably painted... but if you like painting in detail, then fine, it's horses for courses.

Painting and collecting are transformative actions that enable miniatures to open 'up an interior world, lending itself to fantasy and privacy in a way that the abstract space, the playground, of social play does not' (Stewart 1993: 56). Yet, in the case of wargaming, 
players engage with each other. Miniatures become vehicles for sociability through performances of play. The following section looks in more detail at how games are played.

\section{Play}

Rules are the most important part of a wargame. They regulate the game by determining the movement of units across model terrain, the effects of shooting and meleeing, as well as the moral of troops. Dice throws are used to reflect the element of chance that is outside a 'real' general's hands (e.g. would a soldier hit a target with his shot?) and also to bring an element of excitement to the game. The results of dice throws are modified according to circumstances (e.g. was a target in cover? Was the shooter an experienced soldier?) and the complexity of rules is, in part, determined by how many factors are included at this stage. This element of luck distinguishes wargames from chess and, to an extent, has stigmatised them as a tournament of chance rather than skill (Sabin 2012).

To counter this criticism, some sets have complex tables to modify dice throws and make the outcome as realistic or expected as possible. This usually comes at the cost of playability as players take time consulting tables and calculating results, rather than just rolling a dice. Rule writers strive for a balance between authenticity and playability with players choosing sets according to their preferences.

Consequently, there is no definitive set of wargame rules; many are continually being written, revised, released and re-released according to fashions in the hobby and commercial demands. Phil Barker, who is a prolific, full-time rule writer, stated:

\footnotetext{
It is my aim to produce the most accurate and playable rules I possibly can. I work very hard at it, with the aid of a research library of pushing 800 books, plus the resources of a university library and a first-rate city reference library. I now have about 20 years' experience as a rule writer and researcher (Barker 1987: no page number).
} 
As well as being commercially successful, Barker's rules have been credited with providing 'very insightful ideas and research that are of great applicably to combat simulation' (Sabin 2012: xviii).

Authenticity and accuracy of the scaled world is important and many sets of rules, especially early ones, explained how their mechanisms emulated real life. Charles Grant (1973: 11-12) drawing on a 1792 British infantry manual, postulated 'infantry should have three marching speeds, these being i) an ordinary step of 75 paces - each of 30 inches - per minute ii) a quick step of 10 paces and iii) a still quicker step of 120 paces per minute ... and our wargame scale of $1 \mathrm{inch}=10$ yards .. it requires only minimal calculation to reach the conclusion that, on the wargame table, infantry deployed in line has what we might call a standard move of 6 inches per minute'.

At the same time, rules also aim to provide an entertaining game, as another writer, Charles Wesencraft (1974: 8) argued
I have always thought that a game played with easily understood rules that gave a result, played within a broad outline of a particular period that gave enjoyment to both winner and his unfortunate opponent, was to be preferred to one that was so accurate in detail that more often or not no result was achieved apart from one of genuine hostility towards one's enemy of the evening.

Indeed, producing a game that can be played in an evening was a starting point for many writers. One interviewee who wrote rules commented:

\begin{abstract}
No one is able to control more than about fifty elements ... you need to work out your time limit say of three hours and base turns on twenty minutes so you work your rules out based on that mathematical formula.
\end{abstract}


Rules reflect competing ideas about the relative importance of authenticity or playability in wargaming (see Hyde 2013). For example, one gamer derided the simplicity of modern 'fast play' rules as being 'dumbed down' to a game of chance rather than skill:

\begin{abstract}
Kids of thirteen or a bit less ... expect to be spoon-fed to a higher level than kids were when we started, society has dumbed down... What they are calling ‘fast-play' or D6 [six sided dice] wargaming, making it simple, is the real turn-on now. Older games were a picture of complexity that were not impossible to play and actually gave a very good game ... in the previous version you could beat someone by melee or you could beat him by shooting, now there's only one way and that's rolling a D6. It's not such a challenging game.
\end{abstract}

Rules enable different types of play that reflect different imaginative possibilities in the miniature world of the wargame table. Some games are played as competitions in which opponents start with similar armies so that players have an equal opportunity of victory, rather like chess. Here it is possible to field two armies from the same period that would not have met historically. Thus, the game rather than historical accuracy is emphasised. Other games are designed to test out particular tactics or attempt to recreate historical battles, perhaps to test out what might have happened if different decisions or actions had occurred on the day.

As each game unfolds, it reveals various possibilities that resolve into a particular narrative. Play is a one-off event that emerges from many possibilities offered by rules, decisions, dice throws and all the other structures that make up a game (Shaw and Sharp 2013: 344). As Woodyer (2012) notes, questions of 'what if' feature prominently in play, including wargaming, opened up a host of imaginative possibilities: 
what if we got the Maus [Panzer VIII, a super-heavy German tank], the Tortoises [an experimental British heavy tank], these mark II Hetzers [modified versions of German tank destroyers], slightly different design ... how would they have changed the war?

'What if' creates its own reality, not only in comparison to what would have been historically but also in the game's own life-world. The wargame does not provide a totalising image of war but rather is a presentation of its own reality. It is the event of the game itself, its happening, that gives it meaning and positions it as a synthetic whole whose parts 'must be selected, co-ordinated, enter into connections and liaisons'. Interpretation and arguments over rules are sometimes a key part of this process. Some even disregard the rules and cheat to influence how a game unfolds. An interviewee recalled a story told him whereby a gamer moved the figures in the middle of the night to a more advantageous position:

He would cheat and... In the night [name of another player] said "dad I think we have got burglars". "No. No", he said "it's only [name of cheat] moving the figures about". So he would cheat. What was the motivation? Was this the motivation to win? ... He had been in combat and done loads of things and wanted to win at all costs.

Such performances allow games to develop further in their own unique way, as events of their own making. Games should not be understood as a medium but a reality that is given meaning by virtue of its own 'happening' (Deleuze 1989). Rather than having a direct relationship with the reality of war, games were their own realities that bore a rhizomic relationship with not only war but other games and aspects of the hobby. As the following example shows, a desire to win, coupled with the organisational structures of a rule set, can shape collection and organisation:

The thing that drives buying the extra unit is competition ... players will come away from a competition and analyse why they lost and that drives them to buy the extra units 
The example demonstrates how play and classification over-ride history as the prime mover and organisation of collection (Stewart 1993). A desire for a strong tactical army to help win the game may prompt gamers to collect units such as the Waffen SS with little consideration of the atrocities they committed (Smelser and Davis 2007), suggesting a banal disengagement with the politics of war. The following section explores these uncomfortable aspects of wargaming in more detail and considers how war is represented.

\section{$\operatorname{Re}(-)$ creational War: Representations of War in Wargaming}

Games aim to produce an experience of war and what might be deemed a 'reflection of a profound reality' (Baudrillard 1994: 6) in which wargaming takes on its own hyper-reality in the eyes of its participants. One interviewee stated:

obviously you can't create the fear and you wouldn't want to but you can actually produce something in a small area you can say that is a close as you're going to get to the early fifteenth century ... probably as close as you'd want to get.

Yet implicit in this quote is that wargaming, while striving for authenticity, produces a safe, sanitised simulation of war. The representation of death, mutilation and civilian atrocity are so absent (represented only in the removal of counters, figures or symbols) that wargames might, in Baudrillard's (1994: 6) terms, be considered as 'an evil appearance of war', one that 'masks and denatures its profound reality'. Indeed, Baudrillard's work is particularly apposite here. In 'The Gulf War did not take place' (Baudrillard: 1995) he argues that the fighting and death of the first Iraq war were hidden by Western media representations. According to Dunnigan (2005), a recreational board game was used to plan the operation: 'the only kind of wargame that could get results quickly was a manual game, a commercial manual game that could be bought in a game store. The game was called Gulf Strike.' The game's designer was contracted to run the game for Pentagon and it played a significant role in the campaign's 
planning. If confirmed, this story suggests that a wargame, far from being an image, is a form of hyper-reality: 'it is no longer a question of a false representation of reality (ideology) but of concealing the fact that the real is no longer real' (Baudrillard 1994: 12-13).

Killing is portrayed in an extremely sanitised way. Dice are rolled to determine the number of casualties according to a table. If a figure becomes a 'casualty' it is removed from the board, rather like a chess piece. Generally, it is not replaced by a casualty model and so the wargames table is not littered with models of corpses. Death, then, is curiously absent from an activity that seeks to portray war accurately. Equally, pictures of death and killing are usually absent from books or rules about wargaming that increasingly are lavishly illustrated with finely painted figures ${ }^{1}$ (Hyde 2013). One exception is Charles Grant's book 'Battle' (Grant 1970), which depicted a soldier being ripped apart by shrapnel on its front cover. Rules and boxes of figures are often illustrated with heroic-looking pictures. As with media representations of war (Baudrillard 1995), death is also portrayed in wargames as something distant and only marginal to the unfolding action. Following calls from feminist geographers (Katz 2007; Massaro and Williams 2013) it is important to consider how wargames contribute to the othering of certain groups. Thus, games usually portray warfare at the tactical level little, if any, recognition is made of civilian deaths or the ways that women and children are caught up in wars. Wargames present a vision of war that largely reflects a male gaze and one that focuses on fighting rather than the wider social or political effects of war. While Stewart (1993: 76), notes that 'once we attend to the miniature world, the world outside stops and is lost to us'. Superficially, models may be charming but they are sites where the banal may be reproduced. What is not shown by models is equally important as what is.

\footnotetext{
${ }^{1}$ This is largely to promote figures that are produced or tied into specific sets of rules, arguably reducing elements of craft consumption.
} 
Some commentators have suggested that sanitised visions of war produced by "war toys' are harmful (Beresin 1989; Brown 1990; Varney 2000) and, for a period in the 1970s and 1980 s, war game conventions were picketed by peace campaigners who associated their playing with the promotion of the armed forces and militarisation.Yet, none of the gamers I spoke to had had any military experience or a desire to serve. One respondent commented rather meekly:

I certainly don't regard myself as an aggressive person. I wouldn't want to be in the army or anything like that at all.

Indeed, the sedentary nature of the hobby ill-equips its participants for the harsh brutalities of campaigning (Sabin 2002) and the embodied form of outdoor masculinity required by the military (Woodward 2000). It is not therefore a direct recruitment route to the military. Although wargames and war-models offer participants the chance to engage with some of the cultural practices and political practices associated with the armed forces, it appears rare that playing wargames leads to direct, or even indirect, enrolment into the military in the same way that has been attributed to video games as video games (Gregory 2011). In this sense, wargaming does not appear to be socially transformative (Katz 2004, Woodyer 2012). This may be, as I have argued earlier, that wargames have emerged through hobby practices rather than the 'military-industrial-media-entertainment' network and so maintains some distance from the armed forces.

Curiously, though, many of the hobby's pioneers saw active service. Most notably, Brigadier Peter Young was a highly decorated senior commando officer in the Second World War, who subsequently wrote an influential wargame book (Young and Lawford 1967) and also founded the 'Sealed Knot' English Civil War re-enactment society (Crang 1996). Donald Featherstone, one of the hobby's pioneers, was the only survivor when an artillery round 
burst on his section (Featherstone 2009). H G Wells' 'Little Wars' has been revived by a serving army chaplain (White 2013) who has commented "as an army chaplain, having buried a lot of people and had friends of mine killed, I'd hate to think I was trivialising war" http://www.bbc.co.uk/news/magazine-22777029. One interviewee told me that one of his club members had served two tours as a regular in Afghanistan and now served as a reservist. Further research is needed on these aspects of the hobby and whether playing wargames is socially transformative for soldiers, perhaps offering a way of coming to terms with their experiences of war.

Games create an imaginative and literal space that is removed from war. This is sometimes re-enforced through embodied performances. In White's revival of 'Little Wars' participants dress up and humorously pastiche an imagined upper-class language and behaviour of Edwardian England. HG Wells was himself a pacifist who overcame this contradiction, as many players do, by recognizing the fantasy element of wargaming, acting out what I 'might have been in different circumstances' (H G Wells quoted in Peterson 2012: 16). In the same way that war films and stories appear to be popular with soldiers (Lodge 1962) the fantasy of wargaming offers an escape from the brutal reality of military encounter. Young and Lawford's (1967) book, for example used two fictitious states to describe $18^{\text {th }}$ Century fighting and it has been speculated that the use of 'imagine-nations' helped to distance the game from actual conflicts (Hyde 2013).

The historical focus aids this escape: deaths happened in the past and are not connected directly to current events. Although there are 'ultra-modern' games, for many the idea of portraying current operations is inappropriate and disrespectful: 
I'd probably feel uncomfortable doing Afghanistan or something like that personally... but yes some people do... we don't tend to game that and most of us are interested in the historical stuff, Napoleonic's, World War Two and so on.

This may also explain why fantasy or science-fiction games have grown in popularity ${ }^{2}$ : Orcs or space marines have no real world equivalent and so their modelled deaths are less troubling (although one respondent argued that these games are far more 'bloodthirsty' and emphasis the act of killing more graphically).

The recreation of war also may be viewed as a form of thanatourism or voyeurism whereby visitors seek to see places of death (Seaton 1999). Slade (2003), though, points out that these visits can be motivated by a variety of reasons, and not just a ghoulish fixation with death per se. Interviewees said that they did not play wargames to revel in the act of killing or the violence associated with war. This is recognised by one gamer who struggled to articulate the contradiction between fun and death:

we only see the sort of spectacle of war; we don't actually see the horrible side. I don't know why it's sort of....all my life I have been sort of...really sort of interested...

Indeed, death and its reversibility has often been a key part of play. Stewart (1993), for example, notes that toy guillotines were popular toys at the end of the $18^{\text {th }}$ Century. In play, death can occur many times, with participants coming back to life and acting out new roles, perhaps with new consequences. This recalls Stewart's (1993: 69) words that miniatures present 'a diminutive, and thereby manipulative version of experience, a version which is domesticated and protected from contamination ... its repetition of a death that is thereby not a death.' Deleuze (1990) suggests that battle can be considered as an 'eternal event' in which

\footnotetext{
${ }^{2}$ This has been driven largely by the British company 'Games Workshop' that has successfully branded and produced fantasy wargames to the extent that their shops are common place in many UK high streets. This phenomenon deserves greater attention that is beyond the scope of this paper.
} 
death can motivate a search for sense in war. Games can indeed provoke an affective response, as one wargamer whose game focused on the 1944 Normandy landings said:

There was a guy in a wheelchair and he came around and he stopped where the trees were. And he said this is just like it was on the day, I know I was there. And he said because I lay in amongst the trees and tears came down his face ... I said you don't talk about this do you? And he said no. I said you must talk about it. We said it's so important, we don't want any more wars, but we should never ever forget - ever!

Sabin $(2002,2012)$ has argued persuasively that, far from glamorising battle, wargaming furnishes its participants with a well-informed view of warfare that, in turn, develops a better understanding of its horrors than is offered by media such as video games, heroic films or jingoistic books. Indeed, some justify wargaming as a form of remembrance. Phil Barker commented:

The dead of Waterloo are just as dead whether wargamed or not. If I were one of them, I would rather be wargamed than forgotten.

As this section has shown, the way that wargames treat deaths in war is complex. Wargames, on the one hand, are simply games that treat death as something distant and untroubling. On the other, they might be viewed as fulfilling the Deleuzian sense of truth that must 'both interact with the actual facts and yet maintain a sense of impacity' (Williams 2008: 97).

\section{Conclusions}

This paper has sought to explore practices of miniaturisation through a study of figure-based wargaming. After Stewart (1993), it has outlined how scale modelling not only creates representations of reality but also reveals much about the interiority of those who produce scale models. Wargames, while influenced by rules and hobby networks, allow participants to 
imbue their own characteristics on the production of space through models. As this paper has attempted to demonstrate, precisely and beautifully engineered models can provoke a sense of what Woodyer and Geoghegan (2013) refer to as 'enchantment and wonder'.

Stewart (1993) and Koch (2010) argue that miniaturisation can help to fix certain political viewpoints. Certainly, it might be argued that military modelling might be regarded as a simulacrum, something that has lost moorings with the reality of war (Baudrillard 1994). The realities of war are pushed aside so that games are undisturbed and unperturbed by its nature. Equally, the superficially apolitical nature of the hobby helps to present war as a banal cultural rather than political activity (Sidaway 2008). In this sense, the hobby of wargaming has much in common with other forms of media, such as video games or war films (Der Derian 2009), that seek to enrol the public into military viewpoints and, as such, demands fuller attention. Certainly more research is needed on the way the scale models present and entange military, civilians and geopolitics.

Yet, miniaturisation also emphasises the hybrid nature of scale (MacKinnon 2010): on the one hand it is socially constructed in ways to support political visions of the world yet, on the other hand, miniatures rely on scalar narratives to bring them to life. Through the process of craft consumption, models reflect their owner's interiority in far more nuanced ways that video games or films allow. Models do more than represent space, they transform it. Rather than simply presenting a uniform vision of space, the 'fluid and polymorphous process' of play (Woodyer 2012: 315) opens up many imaginative possibilities. As we have seen, the way that war and death are portrayed in games are complex, dependent mainly on the ways that gamers engage and reflect on it. For some, it is barely considered, for others it is something to be grappled with. There is a need to attend to the intricate social and cultural geographies that inform the ways that people make sense of broader political discourses through everyday experiences. Banal geopolitics deserves more than banal study. 
Geographers should not confuse the miniature with the trivial. Far from simplifying the world, miniatures warrant further attention as they have an ability to speak of and for it with perhaps unexpected power and consequence.

To date, play has been treated as an object of study by geographers (Woodyer 2012). I would like to conclude this paper by suggesting that it might also be considered as a way of studying the world. Games, for example, may also lead to better understanding of geopolitical conflicts. The classic boardgame 'Diplomacy' was based on Mackinder's (1904) Heartland Theory and sheds light into how his ideas were played out across territories. Set at the turn of the twentieth century the game revolves around the Great Powers' efforts to gain hegemony in Europe. Its creator Allan Calhamer has noted:

I also studied political geography ... I became re-acquainted with the concept of Geopolitics devised by Sir Halford MacKinder in about 1904 ... The principal element in Geopolitics seems to be the consideration of the effect upon the international power struggle of the particular geometric nature of the divisions of Earth into land and sea. Thus Diplomacy emerged as a game in which land power and sea power are almost equally significant'

\section{(http://www.diplom.org/ diparch/resources/calhamer/invention.htm)}

Methodologies of play might be brought to the fore of geography. Games, such as environmental exercises or mock planning enquiries (Cloke 1987; Walford 2007), have long been employed as pedagogic devices but I question also whether play might be developed as a research technique, as something that can help researchers understand, even empathise, with those they study. Since the 1990s there has been a desire to study 'other groups' and listen to their voices using innovative methodologies. Might playing a wargame lead to greater understanding of the pressures faced soldiers or, at the very least, help us to 
understand better how they perform in a landscape (Woodward 2013)? Although games have been deployed in other disciplines for these ends (Sabin 2012), there remains scope for geographers to undertake more playful engagements with the world.

\section{References}

Allen, T. (2002) The evolution of wargaming from chessboard to Marine Doom, in Cornell, T. and Allen, T. (eds.) War and Games. Woodbridge: Boydell, pp. 231-51.

Anderson, B. and Adey, P. (2011) Affect and security: exercising emergency in uk civil contingencies, Environment and Planning D: Society and Space 29:1092-1109.

Barker, P. (1987) The rule writer's point of view Miniature Wargames.

Baudrillard, J. (1994) Simulacra and Simulation. Michigan: University of Michigan Press

Baudrillard, J. (1995) The Gulf War Did Not Take Place. Bloomington: Indiana University Press.

Beresin, A. (1989) Toy war games and the illusion of two-sided rhetoric, Play \& Culture:218-24.

Brace, C. and Geoghegan, H. (2011) Human geographies of climate change: landscape, temporality, and lay knowledges, Progress in Human Geography 35:284-302.

Brown, K. (1990) Modelling for war? toy soldiers in late Victorian and Edwardian Britain, Journal of Social History 24:237-54.

Campbell, C. (2005) The craft consumer: culture, craft and consumption in a postmodern society, Journal of Consumer Culture 5:23-42.

Carter, S. and McCormack, D. P. (2006) Film, geopolitics and the affective logics of intervention, Political Geography 25:228-45.

Chivallon, C. (2001) Bristol and the eruption of memory: making the slave-trading past visible, Social \& Cultural Geography 2:347-63.

Cloke, P. (1987) Applied rural geography and planning - a simple gaming technique Journal Of Geography in Higher Education 11: 35-45

Cornell, T. and Allen, T. (eds.) (2002) War and Games. Woodbrdige: Boydell Press.

Crang, M. (1996) Magic kingdom or a quixotic quest for authenticity?, Annals of Tourism Research 23:415-31. 
Crewe, L. and Gregson, N. (2003) Second hand culture. Poole: Berg

de Certeau, M. (1984) The Practice of Everyday Life. Berkeley: University of California Press.

Deleuze, G. (1989) Cinema 2: The Time Image. Minneapolis: University of Minnestoa Press.

Der Derian, J. (2009) Virtuous War: Mapping the Military-Industrial-Media-Entertainment-Network, Second Edition New York: Routledge.

Dodds, K. (1996) The 1982 Falklands War and a critical geopolitical eye: Steve Bell and the if... cartoons, Political Geography 15:571-92.

Dunnigan, J. (2005) The Complete Wargames Handbook. New York: William Morrow.

Featherstone, D. (1962) War Games. London: Stanley Paul.

Featherstone, D. (2009) My war - Sargeant Featherstone 7893763, in Curry, J. (ed.) Donald

Featherstone's Lost Tales including Wargaming Rules 300 BC to 1945 Bristol: The History of Wargaming Project, pp. 19-32.

Geoghegan, H. (2013) Emotional geographies of enthusiasm: belonging to the Telecommunications Heritage Group, Area 45:40-6.

Graham, S. (2010) Cities under Siege: the New Military Urbanism London: Verso.

Grant, C. (1970) Battle: Practical Wargaming. Kings Langley: Model \& Allied Publications.

Grant, C. (1973) Napoleonic Wargaming. Kings Langley: Model and Allied Publications.

Griggs, G. (2009) 'Just a sport made up in a car park?': the 'soft' landscape of Ultimate Frisbee, Social \& Cultural Geography 10:757-70.

Heley, J. and Jones, L. (2013) Growing older and social sustainability: considering the 'serious leisure' practices of the over 60s in rural communities, Social \& Cultural Geography 14:276-99.

Herod, A. (2011) Scale. New York: Routledge.

Hofschroer, P. (2004) Wellington's Smallest Victory: The Story of William Siborne \& Great Model of Waterloo: The Duke, the Model Maker and the Secret of Waterloo. London: Faber and Faber.

Huntemann, N. and Payne, M. (eds.) (2010) Joystick Soldiers: the Politics of Play in Military Video Games. Oxon: Routledge.

Hyde, H. (2013) The Wargaming Compendium. Barnsley: Pen and Sword.

Insley, J. (2008) Little landscapes: dioramas in museum displays, Endeavour 32:27-31. 
Katz, C. (2004) Growing up Global: economic restructuring and children's everyday lives. Minneapolis: University of Minnesota Press.

Katz, C. (2007) Banal terrorism: spatial fetishism and everyday practice, in Gregory, D. and Pred, A. (eds) Violent geographies: fear, terror, and political violence. New York: Routledge, pp. 349-361.

Koch, N. (2010) The monumental and the miniature: imagining 'modernity' in Astana, Social \& Cultural Geography 11:769-87.

Lewin, C. (2012) Wargames and their History. Stroud: Fonthill Media

Lodge, D. (1962) Ginger, you're barmy. London: MacGibbon and Kee.

Mackinder, H. (1904) The geographical pivot of history, The Geographical Journal 23:421-3.

MacKinnon, D. (2010) Reconstructing scale: Towards a new scalar politics, Progress in Human Geography 35:21-36.

Marshall, D. (2004) Making sense of remembrance, Social \& Cultural Geography 5:37-54.

Massaro, V and Williams, J (2013) Feminist geopolitics, Geography Compass 7/8: 567-577

Moore, A. (2008) Rethinking scale as a geographical category: from analystis to practice, Progress in Human Geography 32:203-25.

Moser, S. (2010) Creating citizens through play: the role of leisure in Indonesian nation-building, Social \& Cultural Geography 11:53-73.

Muzaini, H. (2013) Scale politics, vernacular memory and the preservation of the Green Ridge battlefield in Kampar, Malaysia, Social \& Cultural Geography 14:389-409.

Pemberton, J (1994) Recollections from 'Beautiful Indonesia' (Somewhere beyond postmodern) Public Culture 6: 241-262

Peterson, J. (2012) Playing at the World: A History of Simulating Wars, People and Fantastic Adventures, from Chess to Role-Playing Games San Diego: Unreason Press.

Purvis, M. and Atkinson, D. (2009) Performing wartime memories: ceremony as contest at the Risiera di San Sabba death camp, Trieste, Social \& Cultural Geography 10:337-56.

Sabin, P. (2002) Playing at war: the modern hobby of wargaming, in Cornell, T. and Allen, T. (eds.) War and Games. Woodbridge: Boydell Publishers, pp. 193-222. 
Sabin, P. (2007) Lost Battles: Reconstructing the Great Clashes of the Ancient World London:

Continuum.

Sabin, P. (2012) Simulating War. London: Continuum.

Saville, S. J. (2008) Playing with fear: parkour and the mobility of emotion, Social \& Cultural Geography 9:891-914.

Seaton, A. V. (1999) War and thanatourism: Waterloo 1815-1914, Annals of Tourism Research $26: 130-58$

Shaw, I. G. R. (2010) Playing war, Social \& Cultural Geography 11:789-803.

Shaw, I. G. R. and Sharp, J. P. (2013) Playing with the future: social irrealism and the politics of aesthetics, Social \& Cultural Geography 14:341-59.

Sidaway, J. (2001) Iraq/Yugoslavia: Banal Geopolitics, Antipode 33:601-9.

Sidaway, J. (2008) The dissemination of banal geopolitics: Webs of extremism and insecurity, Antipode 40:2-8.

Slade, P. (2003) Gallipoli thanatourism: The Meaning of ANZAC, Annals of Tourism Research 30:779-94.

Smelser, R. and Davis, E. (2007) The Myth of the Eastern Front: The Nazi-Soviet War in American Popular Culture. Cambridge: Cambridge University Press.

Smith, R. (2009) Military Simulation and Serious Games: Where We Came from and Where We Are Going. Florida: Modelbenders LLC.

Smith, R. (2010) The long history of gaming in military training, Simulation \& Gaming 41:6-19.

Stahl, R. (2006) Have you played the war on terror?, Critical Studies in Media Communication 23:112-30.

Stebbins, R. A. (2001) Serious leisure, Society 38:53-7.

Stewart, S. (1993) On longing : narratives of the miniature, the gigantic, the souvenir, the collection. Durham: Duke University Press.

Swyngedouw, E. (2000) Authoritarian governance, power, and the politics of rescaling, Environment and Planning D-Society \& Space 18:63-76. 
van Creveld, M. (2013) Wargames: From Gladiators to Gigabytes. Cambridge: Cambridge University Press.

Varney, W. (2000) Playing with "War Fare", Peace Review 12:385-91.

Varutti, M. (2011) Minatures of the nation: ethnic minority figures, mannequins and dioramas in Chinese museums, Museum and Society 9: 1-16

Walford, R. (2007) Using Games in School Geography London: Chris Kingston Publishing.

Wells, H. G. (1913) Little Wars. London: Frank Palmer.

Wesencraft, C. (1974) Practical wargaming. New York: Hippocrene Books.

White, P. (2013) Funny Little Wars: A Gentleman's Preoccupation. Oklahoma: TVAG.

Williams, J. (2008) Gilles Deleuze's Logic of Sense: A Critical Introduction and Guide Edinburgh Edinburgh University Press.

Woodward, R. (2000) Warrior heroes and little green men: Soldiers, military training, and construction of rural masculinities, Rural Sociology 65:640-57.

Woodward, R. (2005) From Military Geography to militarism's geographies: disciplinary engagements with the geographies of militarism and military activities, Progress in Human Geography 29:718-40.

Woodward, R. (2013) Military landscapes: agendas and approaches for future research, Progress in Human Geography, forthcoming

Woodward, R. and Jenkings, K. (2012) Photographic representations of participation in armed conflict, in Gibson, S. and Mollan, S. (eds.) Representations of Peace and Conflict. London: Palgrave McMillan, pp. 105-19.

Woodward, R. and Jenkings, K. N. (2011) Military identities in the situated accounts of british military personnel, Sociology-the Journal of the British Sociological Association 45:252-68.

Woodyer, T. (2012) Ludic geographies: not merely child's play, Geography Compass 6:313-26.

Woodyer, T. and Geoghegan, H. (2013) (Re)enchanting geography? The nature of being critical and the character of critique in human geography, Progress in Human Geography 37:195-214.

Yarwood, R. and Shaw, J. (2010) 'N-gauging' geographies: craft consumption, indoor leisure and model railways, Area 42:425-33. 
Young, P. and Lawford, J. (1967) Charge!: Or, How to Play War Games London: Morgan-Grampian

1

2

3

4

5

6

10

10

11

12

13

14

15

16

17

18

19

20

21

22

23

24

25

26

27

28

29

30

31

32

33

34

35

36

37

38

39

40

41

42

43

44

45

46

47

48

49

50

51

52

53

54

55

56

57

58

59

60
36

URL: http://mc.manuscriptcentral.com/rscg E-mail: scgjrnl@nuim.ie 


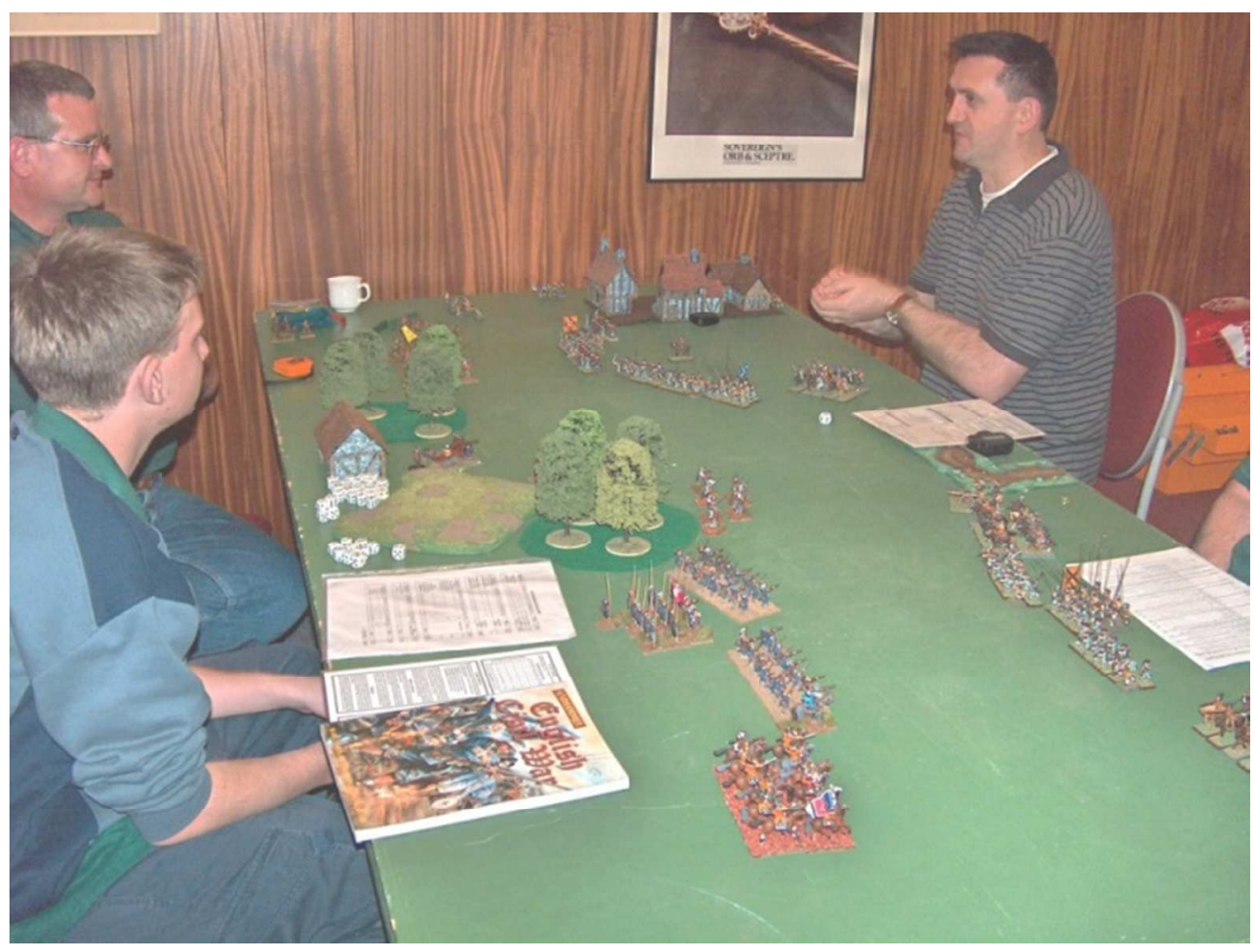

Figure 1: A historical mimiature wargame being played using sets of rules to control scale figures across modelled terrain. $93 \times 70 \mathrm{~mm}(220 \times 220$ DPI $)$ 


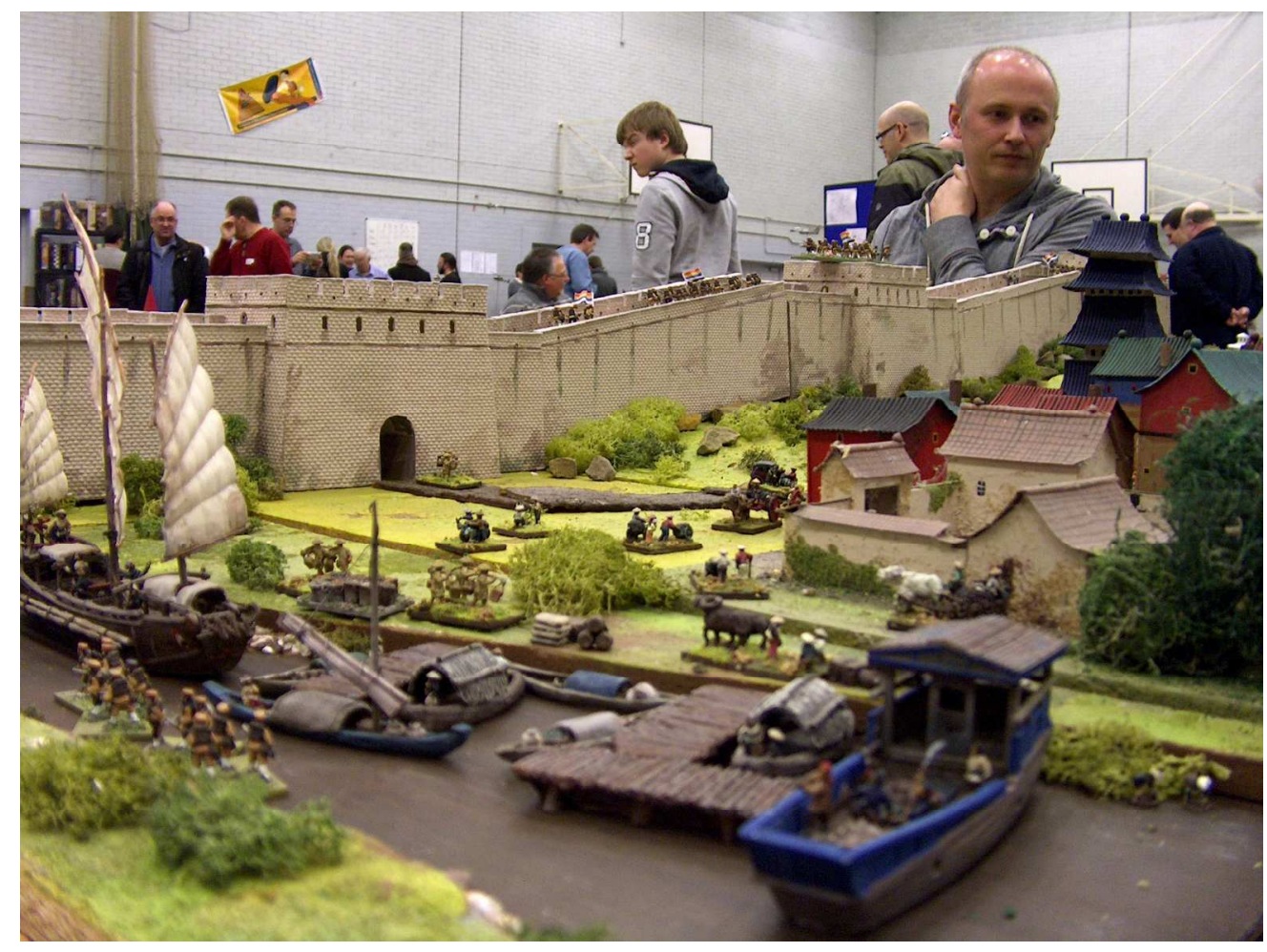

Figure 2: Highly detailed wargames terrain $920 \times 688 \mathrm{~mm}(72 \times 72$ DPI $)$ 